\title{
Pemetaan Digital dan Pengelompokan Lahan Hijau di Wilayah Provinsi Riau Berdasarkan Knoledge Discovery in Databases (KDD) dengan Teknik K-Means Mining
}

\author{
Mustakim \\ Jurusan Sistem Informasi Fakultas Sains dan Teknologi UIN Suska Riau \\ JI. HR. Soebrantas KM. 18 Panam Pekanbaru - Riau \\ Email : mhoezma@yahoo.co.id
}

\begin{abstract}
ABSTRAK
Perkembangan teknologi semakin meningkat disemua kalangan, baik di lingkungan pendidikan, instansi maupun perusahaan, teknologi tersebut salah satunya adalah internet dan pemetaan. Peranan penting peta adalah memberikan informasi kepada pembaca atau akses digital, pada kasus ini dilakukannya pemetaan digital untuk pengelompokan lahan hijau di Riau dengan menggunakan KDD teknik data mining. Lahan hijau yang dimaksudkan pada topik yang dibahas adalah Hutan. Sistem ini memberikan informasi berupa pengelompokan pada daerah kecamatan di Riau, dengan hasil akhir sebuah peta digital lahan hijau, selain itu detail informasi mengenai atribut daerah akan tampil sesuai dengan informasi masing-masing daerah kecamatan. Sistem dikembangkan dengan bahasa pemrograman PHP dengan bantuan mapping pada google maps. Pengguna dari sistem tersebut terdiri atas admin, pimpinan, dan pengguna biasa berdasarkan hak aksesnya masing-masing.
\end{abstract}

Kata kunci : Data Mining , K-Means, Knowledge Discovery in Databases (KDD), Pemetaan digital

\section{ABSTRACT}

Development of technology more rise in all circle, in education, instance and in interprise One of technology are internet and mapping. Significant function of map is giving information to reader or digital access, in this case, digital mapping for grouping green land in Riau by using KDD technique data mining. Green land the topical is forest. This system give information like territory map grouping in Riau, with output a digital maps green land, besides detail information every teritory. This system is developed by programing language PHP with mapping in google maps. User from this system consist of admin, leader and ordinary user based on every access rightfull authority.

Keyword : Data Mining, Digital Mapping, K Means, Knowledge Discovery in Databases (KDD)

\section{PENDAHULUAN}

\subsection{Latar Belakang}

Perkembangan teknologi informasi dan komunikasi saat ini semakin marak dan berkembang dengan pesatnya, hampir seluruh komponen menggunakan jasa kemampuan teknologi untuk berbagai kebutuhan pribadi, kelompok, organisasi, lembaga, pemerintahan maupun instansi. Perkembangan tersebut mengarah kepada pemanfaatan multi guna pembangunan. Salah satu diantara teknologi tersebut adalah internet. Internet diyakini sebagai teknologi multiguna yang menyediakan berbagai informasi yang menyeluruh, bukan hanya informasi berupa teks, grafik, animasi, gambar dan video yang ditampilkan melainkan sebuah fasilitas pemetaan.

Berbicara mengenai pemetaan berarti kita akan berhubungan dengan apa yang disebut dengan peta. Peta merupakan gambaran permukaan bumi yang seolah-olah mendasari sebuah skala yang digambarkan untuk meyatakan bentuk aslinya, peta disini diartikan bukan merupakan peta konvensional melainkan peta digital. Saat ini banyak software dan media yang memfasilitasi mengenai pemetaan permukaan bumi kita, salah satu contohnya adalah google art atau google maps dan sebagainya.

Aplikasi yang telah disediakan secara instan oleh google mempunyai berbagai macam kendala akibat beberapa faktor diantaranya adalah cuaca, kondisi wilayah maupun satelit itu sendiri. Dimisalkan sebuah pemetaan lahan hijau, aplikasi yang disediakan oleh google sering 
kali mengalami permasalan mengenai bentuk dan fisik sebuah peta, sulit membedakan antara lahan hijau yang ada dipermukaan bumi, misalnya apakah hutan, kebun, rumput hijau, lapangan hijau maupun rumah yang beratapkan hijau. Google art dan google maps hanya mampu mendefenisikan sebuah lahan hijau (karena berwarna hijau) tanpa dapat mengelompokkannya dan menentukan jenisnya tanpa adanya data-data tertentu sebagai pendukung.

Di wilayah Provinsi Riau banyak sekali terdapat lahan hijau, baik dipedesaan, maupun diperkotaan. Lahan Hijau di Riau banyak memiliki bergai macam bentuk maupun jenisnya, akan tetapi dalam penelitian ini lahan hijau yang dimaksudkan adalah Hutan. Pemetaan hutan yang dilandasi oleh data-data dari berbagai instansi yang akhirnya akan membentuk suatu kelompokkelompok tertentu. Dalam penelitian ini akan dibangun sebuah software berbasis Geographic Information System untuk menentukan dan mengelompokkan daerah lahan hijau di Provinsi Riau berdasarkan Knoledge Discovery in Databases (KDD) dengan menggunakan teknik data mining.

\subsection{Tujuan}

Adapun tujuan dari penelitian ini adalah:

1. Untuk mengetahui seberapa besar perkembangan ruang lahan hijau di Provinsi Riau setiap tahunnya.

2. Sebagai pemetaan wilayah dan sistem pemantau yang didasari atas data-data yang akurat untuk memberikan peringkat dan persentase seberapa besar tingkat pemanasan global di Provinsi Riau tiap tahunya.

3. Membantu dinas dan instansi terkait dalam membuat sebuah kebijakan mengenai masalah lahan hijau dan sebagai data acuan untuk melaksanakan pembangunan jangka panjang terkait dengan lahan hijau.

\subsection{Batasan Masalah}

Untuk memperkecil pembahasan dari penelitian ini maka penulis memberikan beberapa batasan, diantaranya adalah :

1. Sistem ini hanya menggunakan pemetaan wilayah Kecamatan di Provinsi Riau yang didasarkan titik koordinatnya.

2. Data yang digunakan meliputi data dari Dinas Kehutanan Provinsi Riau dan Badan Pusat Statistik Provinsi Riau

3. Lahan Hijau yang dibahas/ dikelompokkan bukan merupakan beberapa lahan hijau seperti Perkebunan, Ruang Terbuka Hijau dan Lahan Hijau Siklis atau Non-Siklis, akan tetapi Lahan Hijau yang dimaksudkan adalah Hutan yang telah dipublish oleh dinas Kehutanan Provinsi Riau.

4. Pengelompokan lahan hijau dibagi menjadi 4 kelompok/ Cluster.

5. Sistem ini dikembangkan atau berdasarkan pemetaan wilayah riau untuk areal Lahan Hijau berdasarakan data 5 tahun terakhir bukan berdasarkan pengolahan citra digital.

\section{LANDASAN TEORI}

\subsection{Data Mining}

Data mining adalah suatu istilah yang digunakan untuk menguraikan penemuan pengetahuan didalam database. Data mining adalah proses yang menggunakan teknik statistic, matematika, kecerdasan buatan, dan mechine learning untuk mengekstraksi dan mengidentifikasi informasi yang bermanfaat dan pengetahuan yang terkait dari berbagai database besar.

Menurut Gartner Group Data Mining adalah suatu proses menemukan hubungan yang berarti, pola, dan kecenderungan dengan memeriksa dalam sekumpulan besar data yang tersimpan dalam penyimpanan dengan menggunakan teknik pengenalan pola seperti teknik stastistik dan matematika. [12] 


\subsection{Knoledge Discovery in Databases (KDD)}

Knowledge Discovery In Databases (KDD) adalah keseluruhan proses non-trivial untuk mencari dan mengidentifikasi pola (pattern) dalam data, dimana pola yang ditemukan bersifat sah, baru, dapat bermanfaat dan dapat dimengerti. KDD berhubungan dengan teknik integrasi dan penemuan ilmiah, interprestasi dan visualisasi dari pola-pola sejumlah kumpulan data.
Tahapan KDD:[12]
1. Data Selection
2. Pre-processing/Cleaning
3. Transformation
4. Data mining
5. Interpretation/ Evaluation

\subsection{K-Means Clustering}

Data Clustering merupakan salah satu metode Data Mining yang bersifat tanpa arahan (unsupervised). Ada dua jenis data clustering yang sering dipergunakan dalam proses pengelompokan data yaitu hierarchical (hirarki) data clustering dan non-hierarchical (non hirarki) data clustering. K-Means merupakan salah satu metode data clustering non hirarki yang berusaha mempartisi data yang ada ke dalam bentuk satu atau lebih clusterl kelompok.

Metode ini mempartisi data ke dalam cluster/ kelompok sehingga data yang memiliki karakteristik yang sama dikelompokkan ke dalam satu cluster yang sama dan data yang mempunyai karakteristik yang berbeda dikelompokkan ke dalam kelompok yang lain. Adapun tujuan dari data clustering ini adalah untuk meminimalisasikan objective function yang diset dalam proses clustering, yang pada umumnya berusaha meminimalisasikan variasi di dalam suatu cluster dan memaksimalisasikan variasi antar cluster.

Data clustering menggunakan metode K-Means ini secara umum dilakukan dengan algoritma dasar sebagai berikut: [1][7][10]

1. Tentukan jumlah cluster

2. Alokasikan data ke dalam cluster secara random

3. Hitung centroid/ rata-rata dari data yang ada di masing-masing cluster

4. Alokasikan masing-masing data ke centroid/ rata-rata terdekat

5. Kembali ke Step 3, apabila masih ada data yang berpindah cluster atau apabila perubahan nilai centroid, ada yang di atas nilai threshold yang ditentukan atau apabila perubahan nilai pada objective function yang digunakan di atas nilai threshold yang ditentukan

\section{Distance Space Untuk Menghitung Jarak Antara Data dan Centroid}

Beberapa distance space telah diimplementasikan dalam menghitung jarak (distance antara data dan centroid termasuk di antaranya L1 (Manhattan/ City Block) distance space, L2 (Euclidean) distance space, dan Lp (Minkowski) distance space. Jarak antara dua titik $\mathrm{x} 1$ dan x2 pada Manhattan/City Block distance space dihitung dengan menggunakan rumus sebagai berikut: [1][7][10]

$$
D_{L_{1}}\left(x_{2}, x_{1}\right)=\left\|x_{2}-x_{1}\right\|_{1}=\sum_{j=1}^{p}\left|x_{2 j}-x_{1 j}\right|
$$

Sedangkan untuk L2 (Euclidean) distance space, jarak antara dua titik dihitung menggunakan rumus sebagai berikut:

$$
D_{L_{2}}\left(x_{2}, x_{1}\right)=\left\|x_{2}-x_{1}\right\|_{2}=\sqrt{\sum_{j=1}^{p}\left(x_{2 j}-x_{1 j}\right)^{2}}
$$

\subsection{Lahan Hijau}

Lahan Hijau merupakan bagian dari permukaan bumi yang tampak sebagai tempat hidup dan berkembangnya ekosistem (Suparman, 1999). Lahan hijau sendiri memiliki berbagai macam variasi, jenis dan bentuk sesuai dengan tingkat dan keadaan ekosistem. Jika dikaji 
secara menyeluruh lahan hijau memiliki kaitan erat dengan apa yang disebut dengan Hutan, Perkebunan, Ruang Terbuka Hijau (Green Openspaces) dan kelompok tumbuhan hijau yang rimbun. [4][5][11]

\section{METODOLOGI PENELITIAN}

Metodologi penelitian merupakan langkah-langkah yang ditempuh dalam pelaksanaan penelitian dimulai dari pendahuluah hingga alhir dari penelitian.

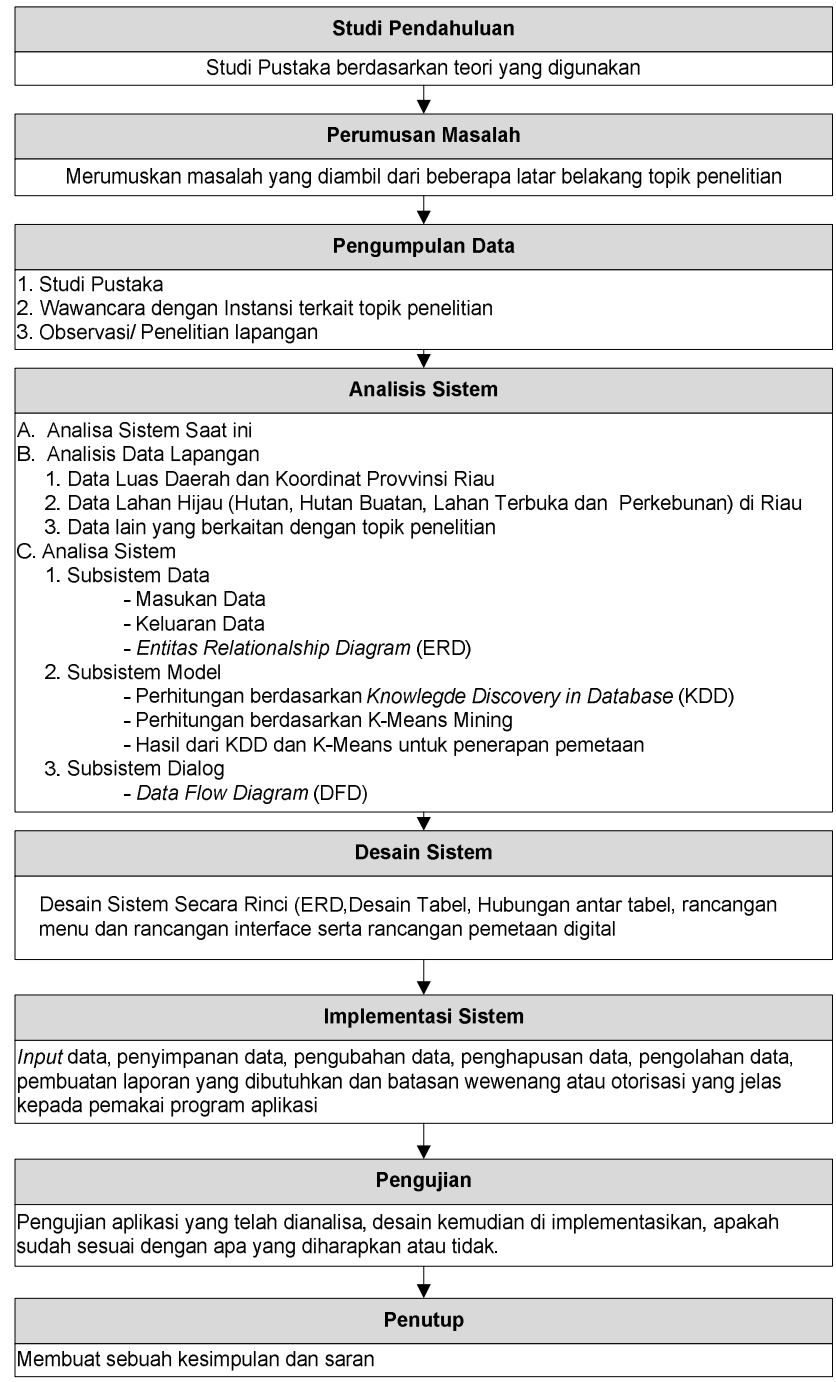

Gambar 1. Metodologi Penelitian

\section{ANALISA PEMBAHASAN DAN HASIL}

Sistem yang akan dibangun merupakan aplikasi yang dikembangkan dari metode $K$ Means. Proses yang dilakukan sistem dalam menganalisa pengelompokkan Lahan Hijau di Riau ini dibangun berdasarkan sistem yang ada pada saat ini yaitu pada Dinas Kehutanan Provinsi Riau yang memasukkan data luas lahan hijau (hutan) yang akan dikelompokkan, data kriteria, data bobot kirteria dan data cluster.

Gambaran umum dari sistem ini adalah pengelompokan lahan hijau di Riau berdasarkan atas data yang dianggap sangat penting untuk melakukan pendataan, diantara beberapa yang dimasukkan data tersebut sedah melalui tahapan KDD. Data lahan hijau akan dikelompokkan dengan menggunakan jarak euclidean. 


\subsection{Analisis Data}

Pada penelitian ini sistem akan menerima masukan data yaitu data kriteria dan data pengelolaan lahan hijau di Riau. Data pengelolaan lahan hijau di Riau berdasarkan data akurat dari Dinas Kehutanan Provinsi Riau sedangkan data kriteria adalah data yang digunakan untuk pengelompokkan lahan hijau di Riau dapat dilihat pada tabel 1. berikut:

Tabel 1. Data Kriteria

\begin{tabular}{|c|c|l|}
\hline No & Kriteria & \multicolumn{1}{c|}{ Nama Kriteria } \\
\hline 1 & C1 & Luas Daerah/ Luas Wilayah \\
\hline 2 & C2 & Luas Hutan \\
\hline 3 & C3 & Jumlah Desa/ Kelurahan \\
\hline
\end{tabular}

Hasil keluaran data dari sistem ini berupa pengelompokan lahan hijau yang difokuskan pada hutan di wilayah Provinsi Riau yang terdiri atas 4 kelompok yang dapat dilihat sistem pemetaannya berdasarkan titik koordinat Kecamatan.

\subsection{Knoledge Discovery in Databases (KDD)}

Peran KDD pada penggunaan data adalah Menyeleksi Data yang akan digunakan. Terdapat banyak data yang terdapat dalam database, namun hanya beberapa yang dijadikan sebagai data utama untuk melakukan proses. Selanjutnya, data yang sudah ditentukan akan di Clening atau dibersihkan serta transformasi data dari beberapa kesalahan-kesalahan sebelum data digunakan. Langkah selanjutnya adalah penggunaan Data Mining atau inti pokok penggunaan data dengan menggunakan beberapa Algoritma.

\subsection{K-Means Clustering}

Data Mining yang digunakan untuk menyelesaikan kasus pengelompokan lahan hijau (hutan) di Riau pada penelitian ini adalah teknik K-Means, dengan uraian langkah-langkah sebagai berikut:

Langkah Pertama adalah memasukkan data lahan hijau (hutan) di Riau yang terdiri atas 155 kecamatan, data tersebut meliputi Luas Wilayah, Luas Hutan, dan Jumlah Desa: [2][3]

Tabel 2. Data Kecamatan di Riau

\begin{tabular}{|c|l|c|c|c|}
\hline No & \multicolumn{1}{|c|}{ Nama Kecamatan } & Luas Wilayah $\left.\mathbf{( K m}^{2}\right)$ & Luas Hutan $\mathbf{( H a )}$ & Jumlah Desa \\
\hline 1 & Batang Tuaka & $1.050,25$ & 14,04 & 11 \\
\hline 2 & Concong & 160,29 & 0,00 & 6 \\
\hline 3 & Enok & 880,86 & 796,91 & 12 \\
\hline 4 & Gaung & $1.479,24$ & $124.890,45$ & 11 \\
\hline 5 & Gaung Anak Serka & 612,75 & $14.934,89$ & 8 \\
\hline 6 & Kateman & 561,09 & 12,18 & 8 \\
\hline 7 & Kempas & 364,49 & 0,00 & 8 \\
\hline$\ldots$ & $\ldots$ & $\ldots$ & $\ldots$ & $\ldots$ \\
\hline$\ldots$ & $\ldots$ & $\ldots$ & $20.708,34$ & 9 \\
\hline 151 & Tebing Tinggi & 810,00 & $14.116,38$ & 8 \\
\hline 152 & Tebing Tinggi Barat & 587,33 & $23.237,50$ & 13 \\
\hline 153 & Rangsang & 680,50 & $2.264,90$ & 15 \\
\hline 154 & Rangsang Barat & 241,60 & $52.008,73$ & 9 \\
\hline 155 & Merbau & 973,91 & & \\
\hline
\end{tabular}

Data diatas terlebih dahulu dinormalisasi untuk memudahkan perhitungan, dengan cara mencari data terbesar kemudian membagi setiap data terhadap data terbesar tersebut,

Maka diperoleh data seperti tabel berikut:

$$
T_{i}=\frac{t_{i}}{\operatorname{Max}_{t}} .
$$

Tabel 3. Normalisasi Data

\begin{tabular}{|c|c|c|c|}
\hline No & Luas Wilayah $\left(\mathbf{K m}^{2}\right)$ & Luas Hutan $(\mathrm{Ha})$ & Jumlah Desa \\
\hline 1 & 0,2477095797 & 0,0000468746 & 0,333 \\
\hline 2 & 0,0378056354 & 0,0000000000 & 0,182 \\
\hline
\end{tabular}




\begin{tabular}{|c|c|c|c|}
\hline 3 & 0,2077576390 & 0,0026611592 & 0,364 \\
\hline 4 & 0,3488901868 & 0,4170541532 & 0,333 \\
\hline 5 & 0,1445218233 & 0,0498729778 & 0,242 \\
\hline 6 & 0,1323374131 & 0,0000406634 & 0,242 \\
\hline 7 & 0,0859677836 & 0,0000000000 & 0,242 \\
\hline$\ldots$ & $\ldots$ & $\ldots$ & $\ldots$ \\
\hline$\ldots$ & $\ldots$ & $\ldots$ & $\ldots$ \\
\hline 151 & 0,0191044760 & 0,0691526012 & 0,273 \\
\hline 152 & 0,1385263199 & 0,0471396550 & 0,242 \\
\hline 153 & 0,1605011845 & 0,0775983597 & 0,394 \\
\hline 154 & 0,0569832273 & 0,0075633026 & 0,455 \\
\hline 155 & 0,2297042007 & 0,1736758482 & 0,273 \\
\hline
\end{tabular}

Langkah selanjutnya adalah menentukan jumlah cluster, adapun cluster yang diinginkan terdiri atas 4 cluster. Kemudian pemberian nilai centroid yang diambil secara acak dari tabel 3 diatas, dengan menggunakan formula:

$$
\mathrm{C}_{\mathrm{j}}=(\operatorname{rand}(0,1), \operatorname{rand}(0,1), \operatorname{rand}(0,1))
$$

Dimana $\mathrm{j}$ adalah nomor index kriteria atau $\{\mathrm{j} \mid \mathrm{I} \leq \mathrm{j} \leq 4, \mathrm{j} € \mathrm{~A}\}$ dan $\mathrm{j}=1 \ldots 4$. Langkah berikutnya adalah menghitung jarak menggunakn rumus Euclidean pada rumus 2.2. index random centroid nya adalah sebagai berikut:

\begin{tabular}{|c|c|c|c|}
\hline 0 & 1 & 0 & $\mathrm{c} 1$ \\
\hline 1 & 0 & 0 & $\mathrm{c} 2$ \\
\hline 0 & 0 & 1 & $\mathrm{c3}$ \\
\hline 1 & 0 & 0 & $\mathrm{c} 4$ \\
\hline
\end{tabular}

Menghitung jarak setiap data yang ada terhadap nilai centroid. Disajikan untuk data pertama adalah sebagai berikut:

$$
\begin{aligned}
& X_{1}=(0,2477095797 ; 0,0000468746 ; 0,333) \quad C_{1,1}=(0 ; 1 ; 0) \\
& D_{1,1}=\sqrt{(0,2477095797-0)^{2}+(0,0000468746-1)^{2}+(0,333-0)^{2}} \\
& =1,0827637785 \\
& X_{1}=(0,2477095797 ; 0,0000468746 ; 0,333) \quad C_{1,2}=(1 ; 0 ; 0) \\
& D_{1,2}=\sqrt{(0,2477095797-1)^{2}+(0,0000468746-0)^{2}+(0,333-0)^{2}} \\
& =0,8228316898 \\
& X_{1}=(0,2477095797 ; 0,0000468746 ; 0,333) \quad C_{1,3}=(0 ; 0 ; 1) \\
& D_{1,3}=\sqrt{(0,2477095797-0)^{2}+(0,0000468746-0)^{2}+(0,333-1)^{2}} \\
& =0,7111993269 \\
& X_{1}=(0,2477095797 ; 0,0000468746 ; 0,333) \quad C_{1,4}=(1 ; 0 ; 0) \\
& D_{1,4}=\sqrt{(0,2477095797-1)^{2}+(0,0000468746-0)^{2}+(0,333-0)^{2}} \\
& =0,8228316898
\end{aligned}
$$

Begitu seterusnya sampai data ke 155 . Hingga diperoleh data sebagai berikut:

Tabel 4. Data Hasil Perhitungan Jarak menggunakan Rumus Euclidean

\begin{tabular}{|c|c|c|c|c|c|c|c|}
\hline No & $\begin{array}{c}\text { Luas Wilayah } \\
\left(\mathbf{K m}^{2}\right)\end{array}$ & $\begin{array}{c}\text { Luas Hutan } \\
(\mathbf{H a})\end{array}$ & $\begin{array}{c}\text { Jumlah } \\
\text { Desa }\end{array}$ & Cluster 1 & Cluster 2 & Cluster 3 & Cluster 4 \\
\hline 1 & 0,24777095797 & 0,0000468746 & 0,333 & 1,0827637785 & 0,8228316898 & 0,7111993269 & 0,8228316898 \\
\hline 2 & 0,0378056354 & 0,0000000000 & 0,182 & 1,0170973981 & 0,9792220619 & 0,8190547928 & 0,9792220619 \\
\hline 3 & 0,2077576390 & 0,0026611592 & 0,364 & 1,0817020870 & 0,8717146582 & 0,6694243766 & 0,8717146582 \\
\hline 4 & 0,3488901868 & 0,4170541532 & 0,333 & 0,7567439024 & 0,8420150038 & 0,8602923768 & 0,8420150038 \\
\hline 5 & 0,1445218233 & 0,0498729778 & 0,242 & 0,9911596386 & 0,8905614734 & 0,7728485620 & 0,8905614734 \\
\hline 6 & 0,1323374131 & 0,0000406634 & 0,242 & 1,0374012623 & 0,9008928237 & 0,7690476065 & 0,9008928237 \\
\hline 7 & 0,0859677836 & 0,0000000000 & 0,242 & 1,0325502279 & 0,9456343934 & 0,7624378586 & 0,9456343934 \\
\hline$\ldots$ & $\ldots$ & $\ldots$ & $\ldots$ & $\ldots$ & $\ldots$ & $\ldots$ & $\ldots$ \\
\hline
\end{tabular}




\begin{tabular}{|c|c|c|c|c|c|c|c|}
\hline$\ldots$ & $\ldots$ & $\ldots$ & $\ldots$ & $\ldots$ & $\ldots$ & $\ldots$ & $\ldots$ \\
\hline 151 & 0,0191044760 & 0,0691526012 & 0,273 & 0,9701659787 & 1,0204500362 & 0,7308027662 & 1,0204500362 \\
\hline 152 & 0,1385263199 & 0,0471396550 & 0,242 & 0,9929259246 & 0,8961744038 & 0,7715780692 & 0,8961744038 \\
\hline 153 & 0,1605011845 & 0,0775983597 & 0,394 & 1,0157626014 & 0,9305740233 & 0,6317369657 & 0,9305740233 \\
\hline 154 & 0,0569832273 & 0,0075633026 & 0,455 & 1,0930641595 & 1,0468760229 & 0,5484751160 & 1,0468760229 \\
\hline 155 & 0,2297042007 & 0,1736758482 & 0,273 & 0,8999754380 & 0,8354035456 & 0,7822102913 & 0,8354035456 \\
\hline
\end{tabular}

Langkah berikutnya adalah menentukan letak cluster dengan cara mebandingakan antara ke empat cluster, nilai minimum merupakan nilai yang menjadi pilihan, jika telah ditemukan nilai yang paling kecil (minimum) maka dapat dimasukkan kedalam cluster tersebut. Lebih jelas lihat tabel 5 dibawah ini:

Tabel 5. Letak atau Posisi Cluster

\begin{tabular}{|c|c|c|c|c|c|c|c|}
\hline No & $\begin{array}{l}\text { Luas Wilayah } \\
\left(\mathrm{Km}^{2}\right)\end{array}$ & $\begin{array}{l}\text { Luas Hutan } \\
\text { (Ha) }\end{array}$ & $\begin{array}{l}\text { Jumlah } \\
\text { Desa }\end{array}$ & Cluster 1 & Cluster 2 & Cluster 3 & Cluster 4 \\
\hline 1 & 0,2477095797 & 0,0000468746 & 0,333 & & & * & \\
\hline 2 & 0,0378056354 & 0,0000000000 & 0,182 & & & * & \\
\hline 3 & 0,2077576390 & 0,0026611592 & 0,364 & & & * & \\
\hline 4 & 0,3488901868 & 0,4170541532 & 0,333 & * & & & \\
\hline 5 & 0,1445218233 & 0,0498729778 & 0,242 & & & * & \\
\hline 6 & 0,1323374131 & 0,0000406634 & 0,242 & & & * & \\
\hline 7 & 0,0859677836 & 0,0000000000 & 0,242 & & & * & \\
\hline$\ldots$ & $\ldots$ & $\ldots$ & $\ldots$ & $\ldots$ & $\ldots$ & $\ldots$ & $\ldots$ \\
\hline & $\ldots$ & $\ldots$ & $\ldots$ & $\ldots$ & $\ldots$ & $\ldots$ & $\ldots$ \\
\hline 151 & 0,0191044760 & 0,0691526012 & 0,273 & & & * & \\
\hline 152 & 0,1385263199 & 0,0471396550 & 0,242 & & & * & \\
\hline 153 & 0,1605011845 & 0,0775983597 & 0,394 & & & * & \\
\hline 154 & 0,0569832273 & 0,0075633026 & 0,455 & & & * & \\
\hline 155 & 0,2297042007 & 0,1736758482 & 0,273 & & & * & \\
\hline
\end{tabular}

Kemudian menentukan nilai centroid baru, nilai ini ditentukan oleh data yang masuk kedalam suatu cluster. Berdasarkan tabel diatas secara lengkap (data 1 - 155) diperoleh nilai sebagai berikut:

- Cluster 1 terdapat 2 data

- Cluster 2 terdapat 0 data

- Cluster 3 terdapat 145 data

- Cluster 4 terdapat 8 data

Untuk menentukan nilai centroid baru (contoh pada cluster 1 terdapat 2 data) dapat dilakukan dengan cara sebagai berikut (contoh untuk penggunaan data secara lengkap):

$C k=\frac{\text { Jumlah dari nilai yang masuk kedalam cluster }}{\text { jumlah data yang masuk }}$

Untuk centroid pertama (c1):

$$
\begin{aligned}
C k_{1} & =\frac{0,3488901868+0,2300509115}{2} \\
& =0,2894705492 \\
C k_{2} & =\frac{0,4170541532+0,3067180125}{2} \\
& =0,36188608283 \\
C k_{3} & =\frac{0,333+0,1512}{2} \\
& =0,24242424242
\end{aligned}
$$


Secara keseluruhan diperoleh nilai centroid baru sebagai berikut:

\begin{tabular}{|c|c|c|c|}
\hline 0,289470549 & 0,361886083 & 0,242424242 & $\mathrm{c} 1$ \\
\hline 0 & 0 & 0 & $\mathrm{c} 2$ \\
\hline 0,118422528 & 0,039941335 & 0,324555904 & $\mathrm{c} 3$ \\
\hline 0,442883914 & 0,207494923 & 0,287878788 & $\mathrm{c} 4$ \\
\hline
\end{tabular}

Untuk mencari nilai centroid kedua dan ketiga samapai ke empat, ulangi langkah diatas. Setelah nilai centroid baru ditemukan, maka ulangi langkah perhitungan jarak yaitu pada langkah sebelumnya hingga memasukkan data kedalam cluster.

Data akhir adalah jika langkah diatas diulang dengan langkah-langkah yang sama hingga menghasilkan data pada suatu cluster tepat sama dari data sebelumnya dengan data pada langkah sesudahnya, atau dengan kata lain data tidak berubah lagi posisinya pada cluster. Posisi data pada setiap cluster terakhir dapat dilihat pada tabel berikut:

Tabel 6. Letak atau Posisi Cluster Terakhir

\begin{tabular}{|c|c|c|c|c|c|c|c|}
\hline No & $\begin{array}{c}\text { Luas Wilayah } \\
\left(\mathbf{K m}^{2}\right)\end{array}$ & $\begin{array}{c}\text { Luas Hutan } \\
(\mathbf{H a})\end{array}$ & $\begin{array}{c}\text { Jumlah } \\
\text { Desa }\end{array}$ & Cluster 1 & Cluster 2 & Cluster 3 & Cluster 4 \\
\hline 1 & 0,2477095797 & 0,0000468746 & 0,333 & & & ${ }^{*}$ & \\
\hline 2 & 0,0378056354 & 0,0000000000 & 0,182 & & & & \\
\hline 3 & 0,2077576390 & 0,0026611592 & 0,364 & & & & \\
\hline 4 & 0,3488901868 & 0,4170541532 & 0,333 & ${ }^{*}$ & & & \\
\hline 5 & 0,1445218233 & 0,0498729778 & 0,242 & & ${ }^{*}$ & & \\
\hline 6 & 0,1323374131 & 0,0000406634 & 0,242 & & ${ }^{*}$ & & \\
\hline 7 & 0,0859677836 & 0,0000000000 & 0,242 & & ${ }^{*}$ & & $\ldots$ \\
\hline$\ldots$ & $\ldots$ & $\ldots$ & $\ldots$ & $\ldots$ & $\ldots$ & $\ldots$ & $\ldots$ \\
\hline$\ldots$ & $\ldots$ & $\ldots$ & $\ldots$ & $\ldots$ & $\ldots$ & $\ldots$ & $\ldots$ \\
\hline 151 & 0,0191044760 & 0,0691526012 & 0,273 & & ${ }^{*}$ & & \\
\hline 152 & 0,1385263199 & 0,0471396550 & 0,242 & & ${ }^{*}$ & & \\
\hline 153 & 0,1605011845 & 0,0775983597 & 0,394 & & & & \\
\hline 154 & 0,0569832273 & 0,0075633026 & 0,455 & & & & \\
\hline 155 & 0,2297042007 & 0,1736758482 & 0,273 & ${ }^{*}$ & & & \\
\hline
\end{tabular}

Berdasarkan data lengkap (1-155) diperoleh tabel pembagian lahan hijau (hutan) pada cluster pertama sebagai berikut:

Tabel 7. Pembagian Lahan Hijau setelah di cluster

\begin{tabular}{|l|c|r|r|c|}
\hline \multicolumn{5}{|l|}{ Cluster 1 } \\
\hline Nama Kecamatan & Kabupaten & $\begin{array}{c}\text { Luas Wilayah } \\
\left(\mathbf{K m}^{2}\right)\end{array}$ & $\begin{array}{c}\text { Luas } \\
\text { Hutan (Ha) }\end{array}$ & $\begin{array}{c}\text { Jumlah } \\
\text { Desa }\end{array}$ \\
\hline Gaung & Indragiri Hilir & $1.479,24$ & $124.890,45$ & 11 \\
\hline Bukit Batu & Bengkalis & $1.128,00$ & $91.543,58$ & 15 \\
\hline Mandau & Bengkalis & 937,47 & $77.088,19$ & 15 \\
\hline Pinggir & Bengkalis & $2.503,00$ & 0,00 & 13 \\
\hline Rengat & Indragiri Hulu & 605,03 & $85.707,76$ & 16 \\
\hline Peranap & Indragiri Hulu & 850,49 & $65.137,99$ & 12 \\
\hline Batang Gansal & Batang Gansal & 950,00 & $67.447,78$ & 10 \\
\hline Langgam & Pelalawan & $1.442,45$ & $59.120,76$ & 8 \\
\hline Ukui & Pelalawan & $1.299,56$ & $42.418,48$ & 12 \\
\hline Teluk Meranti & Pelalawan & $4.239,84$ & $299.458,60$ & 9 \\
\hline Tanah Putih & Rokan Hilir & $1.915,23$ & $26.405,08$ & 16 \\
\hline Sungai Sembilan & Dumai & 975,38 & $91.849,35$ & 5 \\
\hline Sungai Apit & Siak & $1.694,00$ & $63.067,05$ & 15 \\
\hline Sungai Mandau & Siak & $1.106,00$ & $67.247,25$ & 9 \\
\hline Singingi & Kuantan Singingi & $1.953,66$ & $74.792,60$ & 13 \\
\hline Merbau & Meranti & 973,91 & $52.008,73$ & 9 \\
\hline
\end{tabular}

Demikian pula untuk cluster 2, cluster 3 dan cluster 4, data akan membentuk kelompok pada cluster masing-masing seperti halnya pada tabel 7 diatas. 


\subsection{Flowchart Sistem}

Flowchart sistem merupakan gambaran interaksi anata pengguna dengan sistem yang berjalan. Selain itu flowchart sistem dijadikan sebagai alur model rangkuman penggunaan aplikasi secara sistematis.

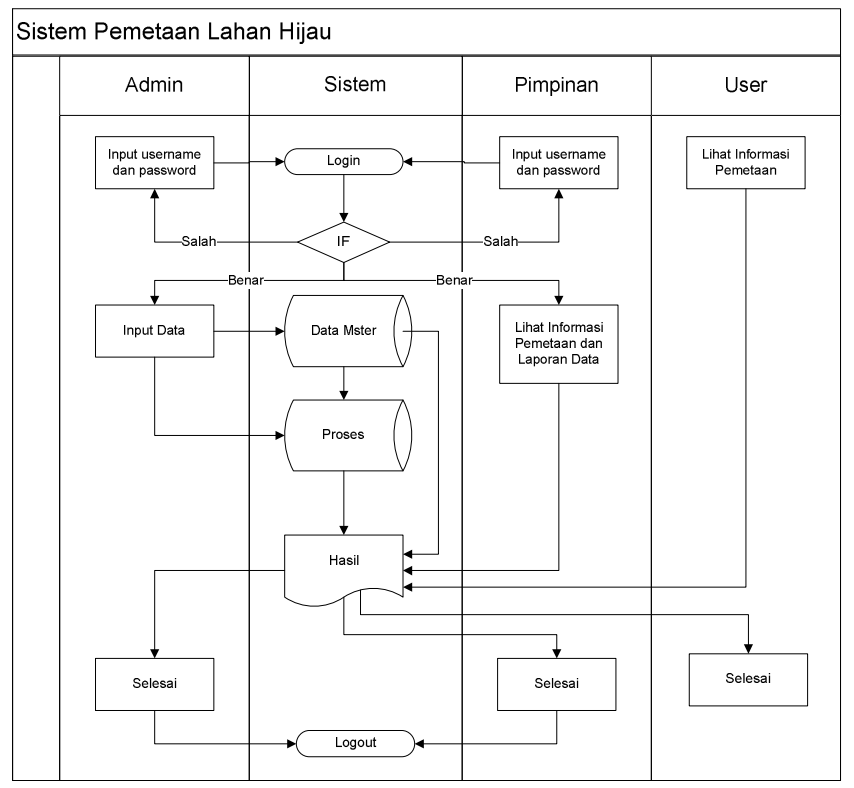

Gambar 2. Flowchart Sistem

\subsection{Implementasi}

Implementasi merupakan hasil dan keluaran yang diharapkan pada penelitian, implementasi ini menggunakan bahasa pemrograman PHP MySql sebagai web server sedangkan untuk pemetaan menggunakan google maps.

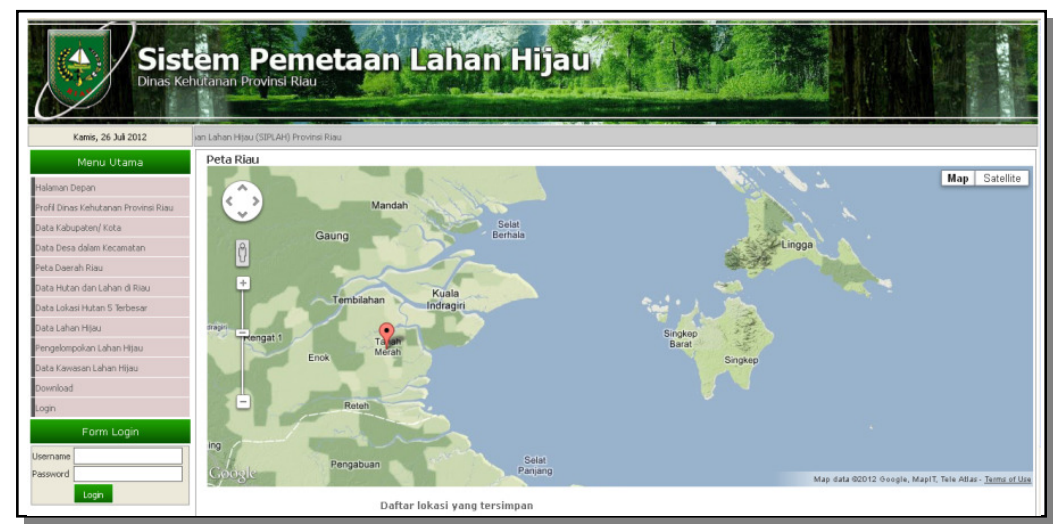

Gambar 3. Pemetaan Lahan Hijau

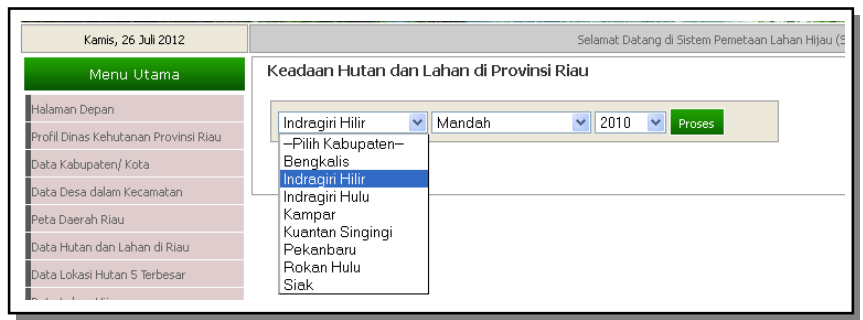

Gambar 4. Pemilihan Data Lahan Hijau Berdasarkan Lokasi Kabupaten dan Tahun 


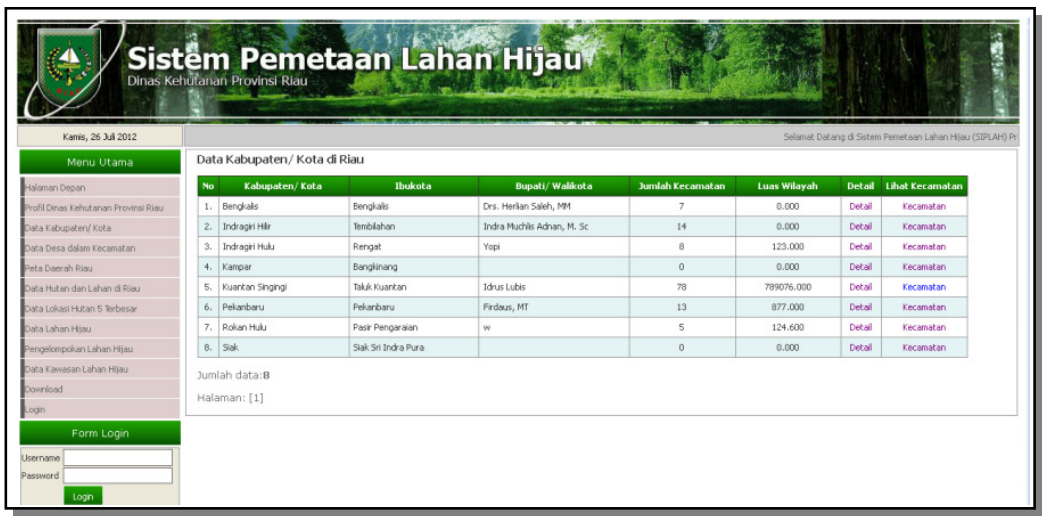

Gambar 5. Data Master untuk Proses Pengelompokan

\section{KESIMPULAN}

Dari pembahasan diatas dapat dihasilkan sebuah kesimpulan sebagai berikut:

1. Metode K-Means memiliki salah satu kelemahan pada nilai centroid yang diberikan diawal dapat mempengaruhi hasil clusterisasi apabila nilainya berbeda (sensitif terhadap nilai centroid awal) akan tetapi salah satu kelebihan $K$-Means adalah beban komputasi relatif lebih ringan sehingga klusterisasi bisa dilakukan dengan cepat walaupun relatif tergantung pada banyak jumlah data dan jumlah cluster yang ingin dicapai

2. Sistem ini mampu memberikan informasi secara lengkap mengenai keadaan suatu daerah yang terdapat pada peta digital.

3. Sistem ini dapat digunakan dalam jangka panjang karena data master yang digunakan bersifat dinamis terhadap kurun waktu dan dapat memilih informasi keadaan pengelompokan setiap tahunnya.

\section{REFERENSI}

[1] Agusta, Yudi. K-Means - Penerapan, Permasalahan dan Metode Tekait. Jurnal Sistem dan Informatika Vol. 3 (Pebruari 2007), 47-60

[2] Badan Pusat Statistik Provinsi Riau. Riau Dalam Angka 2010 berdasarkan Kabupaten, Kecamatan dan Desa.

[3] Dinas Kehutanan Provinsi Riau. Data Luas Hutan di wilayah Riau dalam periode 20102011.

[4] http://www.irwantoshut.net/definisi hutan.html diakses Tanggal 14 Maret 2012

[5] http://rustam2000.wordpress.com/ruang-terbuka-hijau/ diakses Tanggal 14 Maret 2012

[7] Maulani, Kurnia. Rancang Bangun Aplikasi Pengelompokan Sasaran Bisnis dengan Metode Clustering K-Means. Tugas Akhir S1. Riau. UIN Suska Riau. 2012

[8] Prahasta, Eddy. Sistem Informasi Geografis Konsep Konsep Dasar. 2009. Bandung. Informatika

[9] Siswoutomo, Wiwid. Membangun Web Service menggunakan PHP. 2004. Jakarta. Elex Media Komputindo

[10] Tedy Rismawan, Sri Kusumadewi. Aplikasi K-Means untuk Mengelompokkan Mahasiswa berdasarkan Nilai Body Mass Index (BMI) dan Ukuran Kerangka. Seminar Nasional Aplikasi Teknologi Informasi 2008 (SNATI 2008). Jogjakarta. 21 Juni 2008. E-43

[11] Undang-undang No. 8 Tahun 2004 tentang Perkebunan,Hutan, Ruang Terbuka Hijau dan Kelompok Botani.

[12] Wijaya, Sudirman. Teknik Data Mining dan Aplikasinya. 2004. Jogjakarta. Pustaka IImu 